\title{
ANALISIS TEGANGAN PROPELLER KAPAL PENANGKAP IKAN DI KOTA DUMAI MENGGUNAKAN FINITE ELEMENT ANALYSIS
}

\author{
Rizqi Ilmal Yaqin ${ }^{1}$, Juniawan Preston Siahaan ${ }^{1}$, Sigiet Haryo Pranoto ${ }^{2}$ \\ ${ }^{1}$ Program Studi Permesinan Kapal, Politeknik Kelautan dan Perikanan Dumai \\ ${ }^{2}$ Program Studi Teknik Mesin, Fakultas Sains dan Teknologi, Universitas Muhammadiyah Kalimantan
}

Timur

Email: ${ }^{1}$ r.ilmalyaqin@politeknikkpdumai.ac.id

\begin{abstract}
Abstrak
Propeller merupakan salah satu komponen pada kapal penangkap ikan yang memiliki fungsi untuk menggerakan kapal. Efisiensi dari propeller kapal sangat berpengaruh langsung terhadap mesin utama penggerak pada kapal penangkap ikan. Beberapa kondisi, propeller kapal dirancang untuk menyerap daya seminimal mungkin dan memberikan efisiensi gerak kapal semaksimal mungkin. Gaya rotasi propeller kapal akan menciptakan gaya dorong kapal. Gaya yang bekerja pada propeller kapal terjadi karena adanya gaya dari dorongan dan gaya centrifugal serta torsi dari propeller kapal pada setiap blade yang disebabkan revolusi di sekitar sumbu putar propeller kapal. Oleh karena itu, perhitungan tegangan yang dihasilkan dari gaya-gaya pada propeller kapal sangat sulit di perhitungkan secara akurat. Finite Element Analysis (FEA) telah menjadi solusi untuk memprediksi dari suatu kekuatan material yang tidak dapat ditunjukkan dalam teoritis dan memungkinkan desainer untuk melihat semua gaya secara teoritis yang terjadi pada model. Penelitian ini menggunakan material paduan tembaga yang memiliki number of element sebesar 406674 dan jumlah nodes 640321. Hasil yang didapatkan yaitu tegangan maksimu Von Mises yaitu sebesar 2,068 $\times 10^{5} \mathrm{Mpa}$. Sedangkan nilai regangan maksimum yaitu sebesar 0,2448 dan nilai displacement maksimum sebesar $133 \mathrm{~mm}$. Nilai safety factor pada penelitian ini sangat rendah yaitu 0. Sehingga geometri desain model propeller sangat rawan terjadi kegagalan atau deformasi saat diaplikasikan.
\end{abstract}

Kata Kunci: Tegangan Von Mises, Displacement, Faktor Keamanan, Finite Element Analysis, Propeller

\begin{abstract}
Propeller is a component of a fishing vessel that has a function to move the ship. The efficiency of a ship propeller has a direct effect on the main engine driving on a fishing vessel. Some conditions, ship propellers are designed to absorb as little power as possible and provide the maximum efficiency of ship movements. The rotation type of the ship's propeller will create the thrust of the ship. The force acting on the ship propeller occurs because of the force of the impulse and the centrifugal force and torque of the ship propeller on each blade caused by the revolution around the rotating axis of the ship propeller. Therefore, the calculation of the stress generated from the forces on the ship propeller is very difficult to calculate accurately. Finite Element Analysis (FEA) has become a solution for predicting from a material strength that cannot be shown in theory and allows designers to see all the theoretical styles that occur in the model. This study uses copper alloy material that has the number of element of 406674 and the number of nodes 640321. The results obtained are the maximum von mises stress which is equal to 2,068 $\times 10^{5} \mathrm{Mpa}$. While the maximum strain value is equal to 0.2448 and the maximum displacement value is $133 \mathrm{~mm}$. The safety factor value in this study is very low at 0 . So, the design geometry of the propeller model is very prone to failure or deformation when applied.
\end{abstract}

Keywords: Von Mises Stress, Displacement, Safety Factor, Finite Element Analysis, Propeller. 


\section{PENDAHULUAN}

Indonesia adalah negera maritim yang besar dengan luas lautannya 5,9 juta $\mathrm{km}^{2}$ dan panjang garis pantainya yaitu $81.000 \mathrm{~km}$ (Lasabuda, 2013). sehingga Indonesia memiliki kekayaan laut yang sangat melimpah. Salah satu cara pemanfaatan dari sumber daya laut yaitu dengan penangkapakan ikan yang ada di laut. Kapal penangkap ikan menggerakkan kapal dengan menggunakan propeller. Propeller pada kapal umumnya berguna untuk mentransformasikan gerak rotasi dari mesin penggerak menjadi gaya dorong untuk membantu kapal bergerak maju atau mundur. Kerja dari propeller itulah yang membuat gaya penggerak kapal menjadi besar saat laju kapal rendah (Babu \& Padmanabhan, 2017). Propeller sangat berperan dalam efisiensi terhadap bahan bakar pada mesin utama penggerak kapal penangkap ikan saat bergerak (Zainol \& Yaakob, 2016). Jadi, hasil kerja dari propeller sangat mempengaruhi kemampuan mesin penggerak utama pada kapal (Tan, Li, Li, \& Liu, 2019). Propeller kapal penangkap ikan biasanya menggunakan material paduan aluminium atau paduan tembaga. Material tersebut digunakan karena memiliki kekuatan yang tinggi, keuletan yang baik, ringan, mudah di bentuk serta ketahanan korosi dan erosi yang baik di lingkungan air laut (Khashan, Khaleel, \& Meteab, 2017).

Propeller kapal merupakan komponen kunci dari mekanisme gerak kapal dan memainkan peran utama dalam sistem propulsi pada kapal(Ishak, Sulaiman, Baharudin, \& Syajaratunnur, 2017). Efisiensi propeller pada kapal ditentukan pada perancangan dari proepeller kapal, karena terkait langsung dengan efisiensi dan stabilitas pada kapal (Carlton, 2007). Beberapa kondisi, propeller kapal dirancang untuk menyerap daya seminimal mungkin dan memberikan efisiensi gerak kapal semaksimal mungkin. Gerak rotasi propeller kapal akan menciptakan gaya dorong kapal. Hal ini menyebabkan alasan utama kelemahan struktur propeller terhadap erosi permukaan blade dan pengurangan ketebalan blade pada propeller kapal. Hal tersebut menyebabkan aliran kavitasi yang tinggi pada permukaan blade dan potensi tegangan pada blade tidak seimbang pada propulsi kapal.

Perbedaan tekanan yang dihasilkan antara permukaan blade pada sisi depan dan belakang yang berbentuk airfoil dan fluida ketika propeller bergerak dipercepat. Dinamika gerak propeller dapat dimodelkan dengan hukum kedua Bernoulli dan hukum ketiga newton (Reddy \& Rao, 2015). Gaya yang terjadi pada propeller terjadi ketika adanya pergerakan rotasi dari propeller tersebut. Hubungan dari pergerakan propeller yang bergerak melawan tahanan air yang terhadap torsi mesin penggerak menjadikan gaya dorong dan mengatasi resistansi kapal untuk menghasilkan gerak laju pada kapal (Oladokun, 2016). Namun, hasil dari gerakan tersebut menyebabkan blade pada propeller akan mengalami deformasi yang disebabkan gaya dari resistansi pada propeller tersebut.

Gaya yang bekerja pada propeller kapal terjadi karena adanya gaya dari dorongan dan gaya sentrifugal serta torsi dari propeller kapal tersebut pada setiap blade yang disebabkan revolusi di sekitar sumbu putar propeller kapal. Oleh karena itu, perhitungan tegangan yang dihasilkan dari gaya-gaya pada propeller kapal sangat sulit di perhitungkan secara akurat (Rao, Rao, \& Reddy, 2012). Finite Element Analysis adalah salah satu metode yang sangat popular dan banyak digunakan oleh peneliti dalam menganalisis tegangan dan menganalisis parameter lainnya (Lin, Lai, \& Kuo, 2010). Finite Element Analysis (FEA) telah menjadi solusi untuk memprediksi dari suatu kekuatan material yang tidak dapat ditunjukkan dalam teoritis dan memungkinkan desainer untuk melihat semua gaya secara teoritis yang terjadi pada model (Rahmi, Canra, \& Suliono, 2018)(Fadiji, Coetzee, Berry, Ambaw, \& Opara, 2018). Permodelan FEA menjadi alat untuk mengoptimalkan dalam perancangan suatu mesin (Pranoto \& Mahardika, 2018) dan komponen mesin. Oleh karena itu, Permodelan Finite Element Analysis (FEA) dapat digunakanan untuk menentukan kemampuan propeller terhadap tegangan yang terjadi pada bagian permukaan blade. FEA merupakan metode yang penting dalam menganalisis diantara metode CAE. Permodelan FEA memiliki tahapan pertama dengan pembuatan virtual dari bagian yang akan dianalisis dan menentukan komponen penyusun model tersebut seperti jenis material (Rahmi, Canra, \& Suliono 2018) bentuk geometri dan sifat karakteritik dari model tersebut. Strategi pembagian elemen yang dirakit dihubungkan dengan node.

Penelitian sebelumnya menyatakan bahwa Finite Element Analysis dapat menganalisa konsentrasi tegangan atau distribusi tegangan dan displacement pada suatu bentuk dan geometri tertentu (Pratama \& Mahardika, 2018). Sedangkan perhitungan tegangan pada elemen-elemen pada Finite Element Analysis dapat di jabarkan sebagai berikut:

$\left\{\begin{array}{l}\sigma_{x x} \\ \sigma_{y y} \\ \sigma_{z z}\end{array}\right\}=\frac{E}{(1+v)(1-2 v)}\left\{\begin{array}{l}(1-v) \varepsilon_{x}+v \varepsilon_{y}+v \varepsilon_{z} \\ v \varepsilon_{x}+(1-v) \varepsilon_{y}+v \varepsilon_{z} \\ v \varepsilon_{x}+v \varepsilon_{y}+(1-v) \varepsilon_{z}\end{array}\right\}$

Dimana $\mathrm{E}$ adalah modulus young suatu bahan, $l$ adalah panjang dari geometri bahan yang di modelkan (Dapas, 2011). Propeller dapat disimulasikan dengan menggunakan Finite Element Analysis menggunakan beberapa software yang sudah disediakan. Hasil dari simulasi propeller yang telah dilakukan dapat mendapatkan von misses stress, tegangan berdasarkan arah kerjanya, strain dan safety factor serta kecepatan dan tekanan yang ada pada blade propeller kapal dapat dihasilkan (Reddy \& Rao, 2015). Penelitian yang lain membahas permodelan propeller dengan bahan komposit dengan sofware CATIA. Hasil yang didapatkan nilai kekuatan yang dihasilkan dari bentuk geometri propeller yang kompleks dengan kemiringan pitch pada propeller kapal (Suneetha, Rao, Vardhan, \& Gowd, 2013). Sedangkan penelitian yang membahas tentang bentuk kompleks 3D pada blade propeller kapal dengan bahan perbandingan aluminium, Glass Fiber Reinforced Plastic (GFRP) dan Carbon Fiber Reinforced Plastic (CFRP). Hasil dari permodelan Finite Element Analysis dapat menyarankan bahan yang cocok dengan model propeller (Kishore S., Rao, \& Babu, 2015).

Berdasarkan permasalahan dan paparan yang sudah dijelaskan diatas, penelitian ini melakukan analisis kekuatan dari propeller kapal yang ada di kota Dumai 
akibat pengaruh pembebanan hasil dari gaya dorongan thrust yang dihasilkan dari pergerakan kapal yang ada menggunkan Finite Element Analysis (FEA). Analisis FEA dapat memprediksi dari kekuatan yang ada pada propeller kapal yang telah di fabrikasi sehingga dapat mengetahui umur dari propeller kapal yang digunakan.

\section{METODE}

Simulai Finite Element Analysis (FEA) dan gambar 3D model propeller kapal penangkap ikan menggunakan software Autodesk Inventor 2017. Model dari propeller kapal didapatkan dari bengkel kapal yang ada di kota Dumai. Pencarian data yang didapatkan dari kapal yang sedang di perbaiki. Model bentuk geometri dari propeller kapal yang akan diteliti ditunjukkan oleh Tabel 1. Bahan yang digunakan untuk penelitian permodelan propeller yaitu menggunakan paduan tembaga coran dengan sifat mekanik ditunjukkan pada Tabel 2. Bentuk mesh pada penelitian ini yaitu tetrahedral dengan jumlah number of element yaitu 406674. Sedangkan jumlah node pada mesh penelitian yaitu 640321 dengan boundary condition pada sisi dalam propeller berbentuk fixed constraints. Nilai gaya dorong atau thrust force pada blade propeller yang digunakan yaitu $232700 \mathrm{~N}$.

Tabel 1. Geometri bentuk dari propeller kapal

\begin{tabular}{cc}
\hline Geometri & Nilai \\
\hline Diameter luabang Poros & $40 \mathrm{~mm}$ \\
Diameter propeller & $120 \mathrm{~mm}$ \\
Jumlah blade & 3 \\
Tebal Blade & $3 \mathrm{~mm}$ \\
Panjang blade & $80 \mathrm{~mm}$ \\
Putaran propeller & Ke kanan \\
Pitch propeller & $120 \mathrm{~mm}$ \\
\hline
\end{tabular}

Tabel 2 Sifat mekanis dari bahan propeller kapal

\begin{tabular}{cc}
\hline Sifat & Nilai \\
\hline Densitas & $7,64 \mathrm{~g} / \mathrm{cm}^{3}$ \\
Modulus young & $110 \mathrm{GPa}$ \\
Poisson ratio & 0,32 \\
Yield strength & $240 \mathrm{Mpa}$ \\
Tensile strength & $585 \mathrm{Mpa}$ \\
Shear modulus & $42 \mathrm{Gpa}$ \\
Sifat & Isotropik \\
\hline
\end{tabular}

Nilai gaya dorongan thrust pada propeller kapal penangkap ikan dihitung menggunakan persamaan (1) dengan data kapal saat bergerak di daerah Dumai yang ditunjukkan pada Tabel 3. Beban yang didapatkan di distribusikan pada blade propeller kapal penangkap ikan yang sangat rentan terhadap gaya yang dihasilkan oleh kecepatan air saat bergerak. Gambar 1. Menunjukkan hasil mesh dan pengaplikasian beban merata pada blade propeller kapal. Hasil yang akan ditunjukkan yaitu Von Mises Stress, Tegangan pertama, tegangan ketiga, Displacement, Regangan, dan Angka keamaanan dari propeller yang diaplikasikan dengan distribusi beban.
Tabel 3 Laju kapal di perairan Dumai

\begin{tabular}{ll}
\hline Kecepatan kapal & $4 \mathrm{~s} / \mathrm{d} .7$ knots \\
\hline RPM kapal & $240 \mathrm{rpm}$ \\
\hline
\end{tabular}

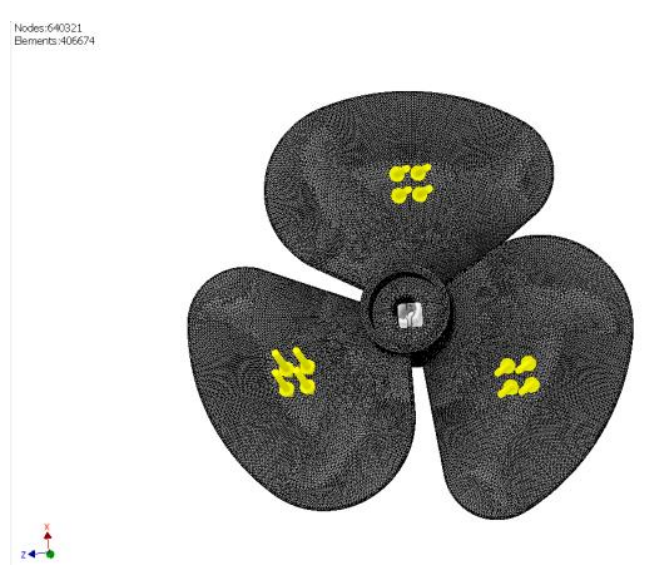

Gambar 1. Penggunaan tetrahedral pada mesh propeller kapal

\section{HASIL DAN PEMBAHASAN}

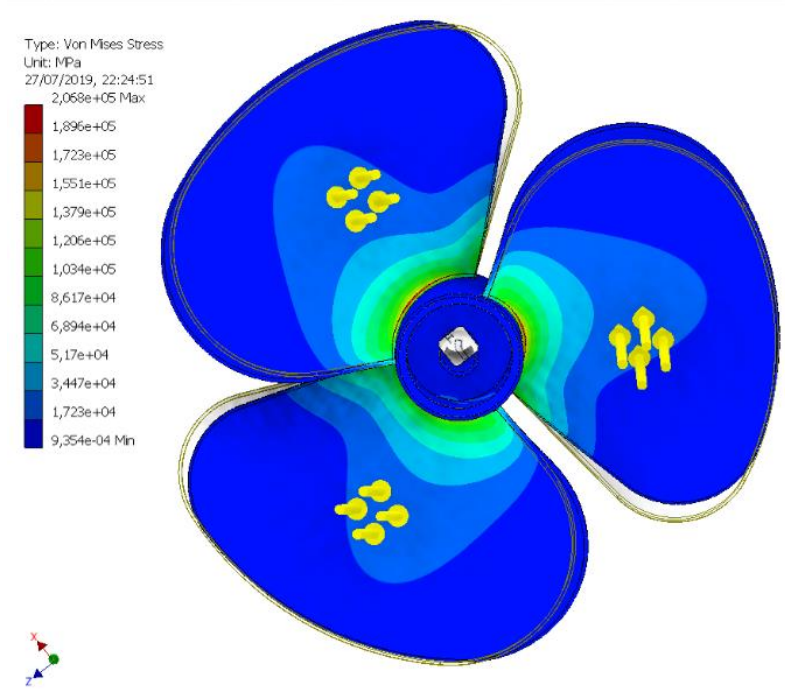

Gambar 2. Tegangan Von Mises pada propeller

Permodelan Finite Element Analysis (FEM) dari propeller kapal mendapatkan hasil yaitu tegangan Von Mises, tegangan utama, displacement dan angka keamaan yang dihasilkan dari perhitungan. Hasil dari tegangan Von Mises dari propeller kapal dapat ditunjukkan pad Gambar 2. Hasil Permodelan Finite Element Analysis (FEM) didapatkan tegangan Von Mises maksimum pada daerah sambungan antara blade propeller dengan lubang poros propeller sebesar 2,068 $\times 10^{5} \mathrm{Mpa}$. Fenomena tersebut dikarenakan adanya tumpuan jepit yang terjadi pada blade propeller sehingga konsentrasi tegangan akan menjadi ke titik terdekat dari sambungan tersebut. Sedangkan titik terjauh dari tumpuan tidak akan tertahan oleh tumpuan sehingga akan menjadi tegangan yang sangat kecil (Syafrizal, 2017) (Saputro, Hidayat, \& 
Qomaruddin, 2017). Daerah yang memiliki tegangan yang paling besar menjadi daerah yang paling kritis karena menerima beban yang sangat besar.

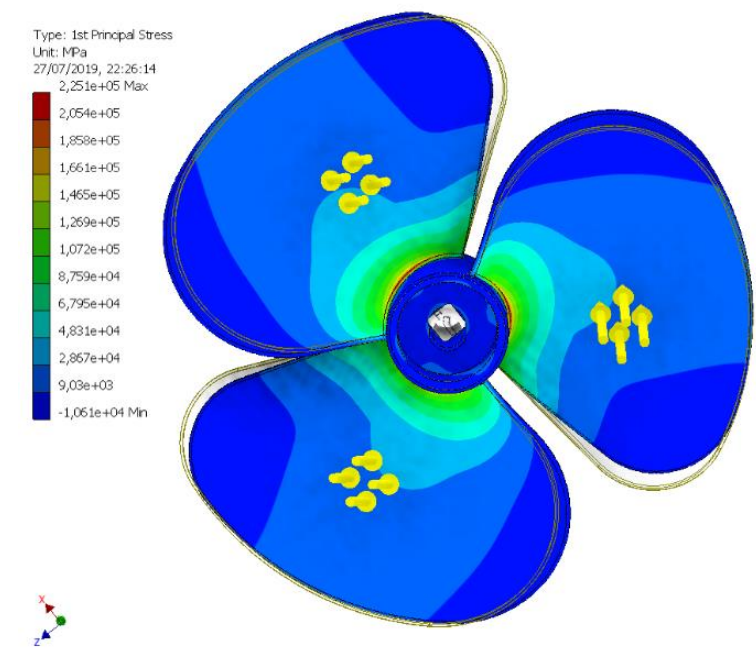

Gambar 3. Tegangan utama 1 pada propeller

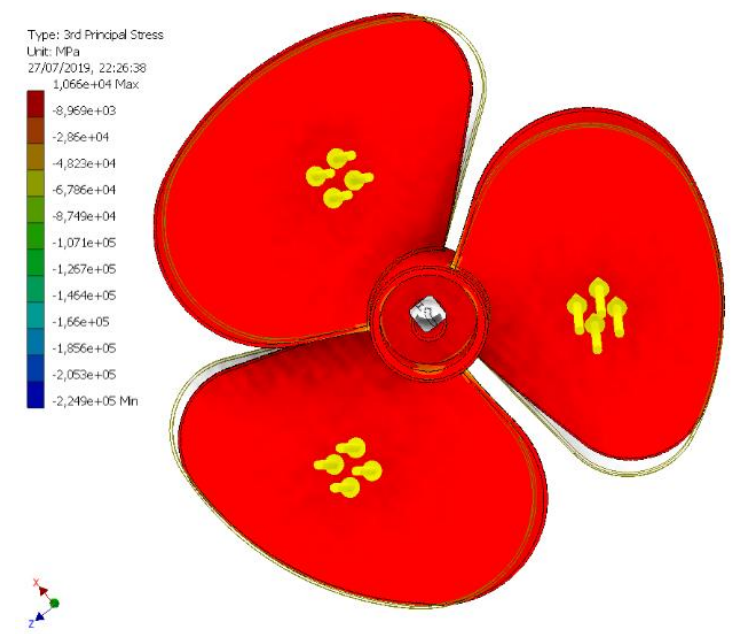

Gambar 4. Tegangan utama 3 pada propeller

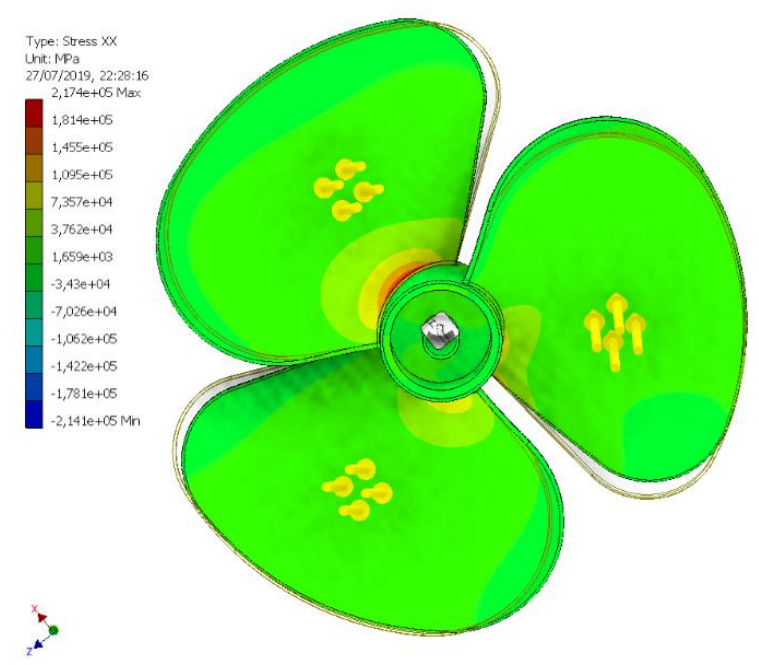

Gambar 5. Tegangan pada arah X-X

Tegangan Von Mises di perkuat dengan adanya tegangan utama yang di tunjukkan pada Gambar 3 dan
Gambar 4 yaitu tegangan yang dihasilkan tegak lurus terhadap bidang kerjanya. Tegangan utama memiliki nilai $2,251 \times 10^{5} \mathrm{Mpa}$ dan 1,066 $\times 10^{4} \mathrm{Mpa}$. Tegangantegangan utama yang dihasilkan, terjadi tegangan yang dominan dari tegangan utama yang lainnya (Wandono, 2017).

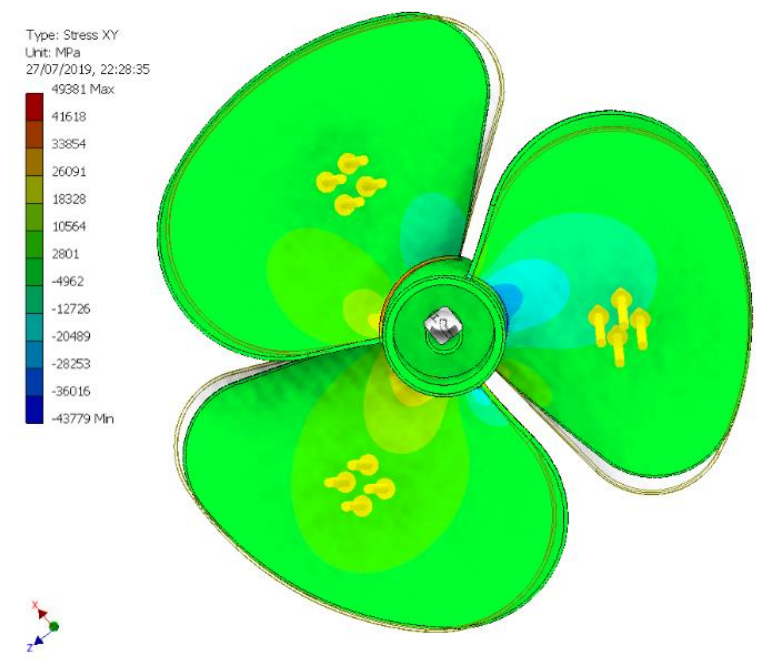

Gambar 2. Tegangan pada arah X-Y
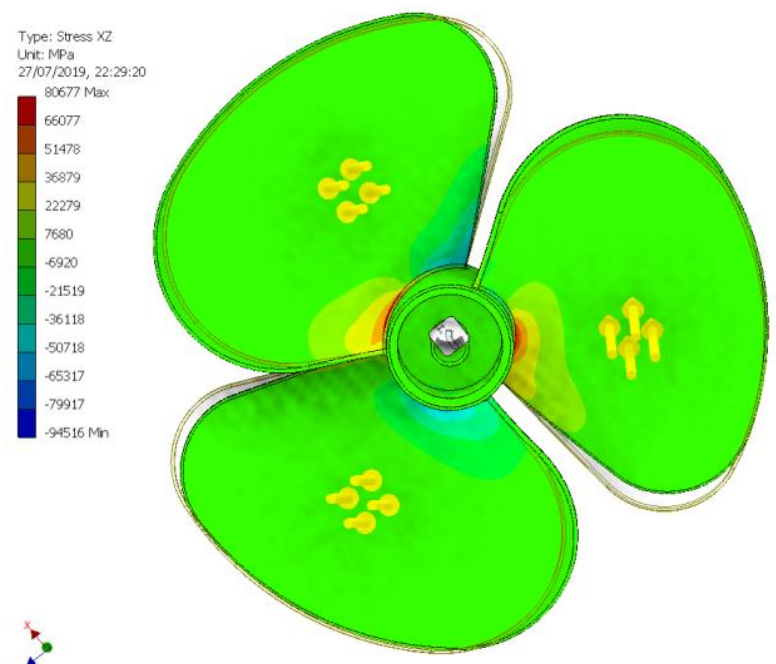

Gambar 7. Tegangan pada arah X-Z

Tegangan Von Mises di perkuat dengan adanya tegangan yang terjadi setiap arah pada propeller yang ditunjukkan Gambar 5. sampai dengan Gambar 10. Daerah yang memiliki tegangan terbesar berada pada bagian yang mendekati sambungan blade dengan lubang poros dari propeller. Hal tersebut menunjukkan bahwa tegangan yang diberikan pada propeller terhadap arah $\mathrm{Y}$ dapat mempengaruhi nilai tegangan pada sumbu lainnya (sumbu $\mathrm{X}$ dan sumbu Z). Tegangan yang terjadi pada sumbu lainnya dinamakan tegangan geser. Tegangan geser dapat terjadi pada suatu bentuk geometri yang memiliki sudut dan adanya perubahan bentuk dari suatu geometri tersebut akibat pengaruh tegangan tegak lurus pada bidang kerja (Rodriguez \& Lade, 2013) sehingga perlu adanya kesetimbangan. Peristiwa tersebut dapat ditunjukkan pada Gambar 11. 


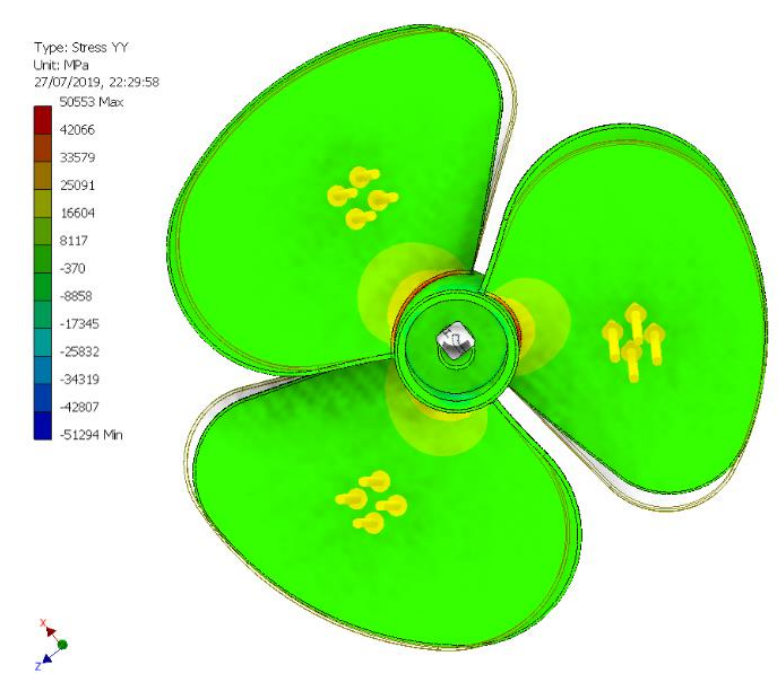

Gambar 8. Tegangan pada arah Y-Y

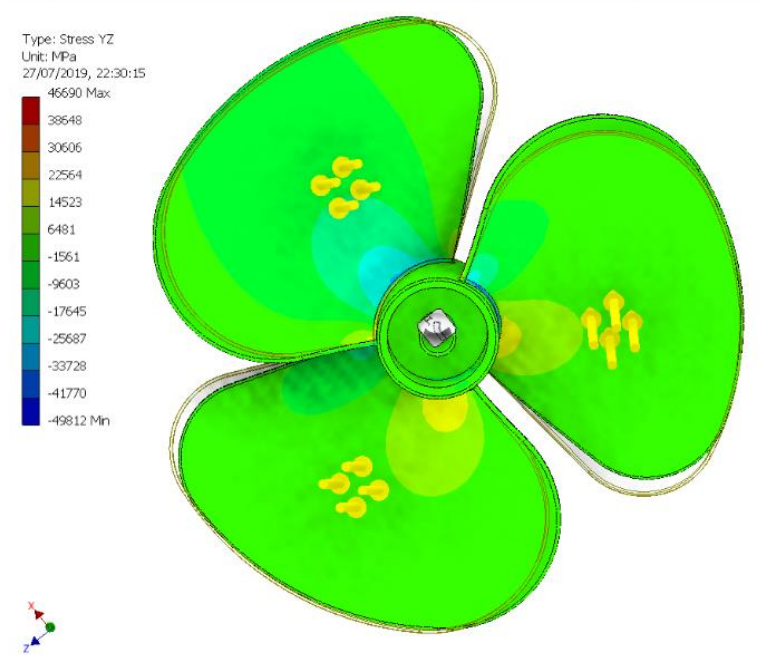

Gambar 9. Tegangan pada arah Y-Z

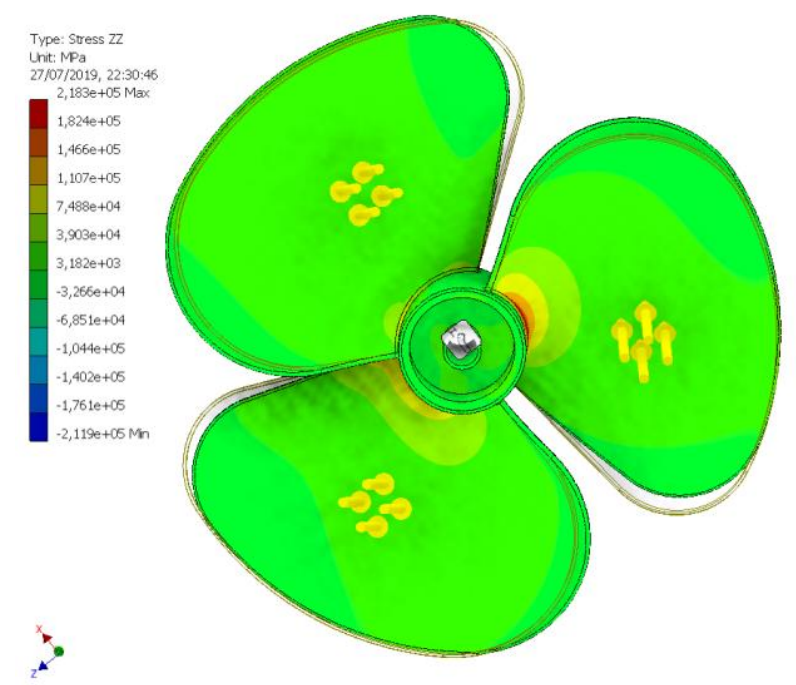

Gambar 3 Tegangan pada arah Z-Z

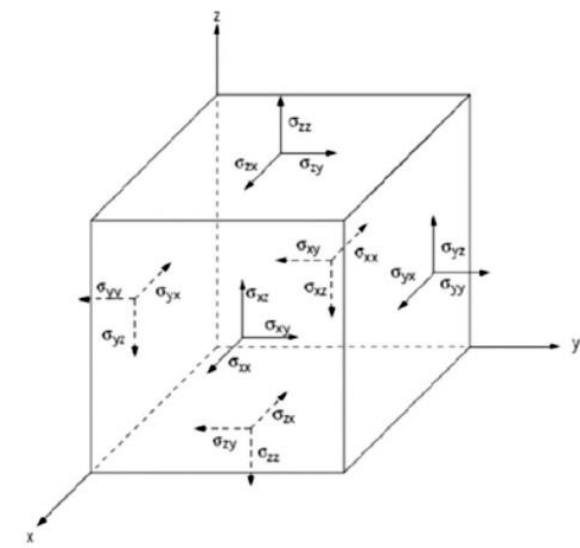

Gambar 4 Tegangan utama pada 3-Dimensi

Penentuan tegangan pada 3 dimensi dengan metode Finite Element Analysis mengakibatkan adanya perubahan nilai regangan. Nilai regangan sangat berkaitan dengan jumlah pembebanan yang terjadi pada propeller kapal (Ramadhan, Mangalla, \& Samhuddin, 2018) sehingga adanya keterkaitan tegangan dan regangan sangat erat. Hal tersebut terlihat pada Gambar 2 dan Gambar 12 yang memiliki kesamaan kontur distribusi antara tegangan dan regangan yang terjadi pada propeller kapal. Kesinambungan bentuk kontur permodelan Finite Element Analysis propeller pada parameter tegangan dan regangan dapat dibuktikan dengan adanya persamaan sebagai berikut:

$$
\sigma=E \varepsilon
$$

Dimana $\sigma$ adalah tegangan, $\varepsilon$ adalah regangan dan $\mathrm{E}$ adalah modulus young dari material propeller. Karena nilai Modulus Young tetap pada penelitian ini sehingga dapat diartikan bahwa:

$$
\sigma \approx \varepsilon
$$

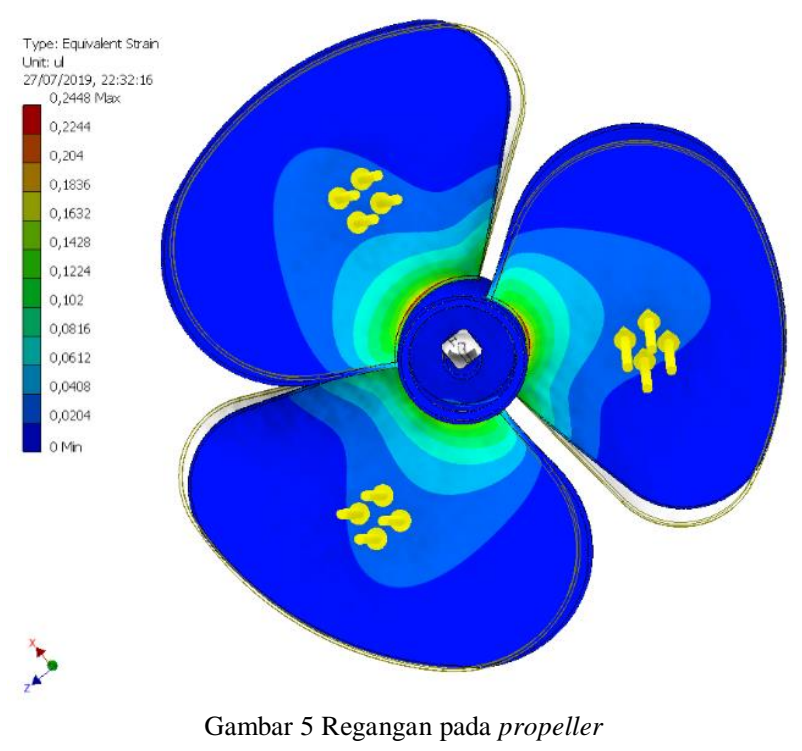

Tegangan yang ada pada propeller kapal mengakibatkan adanya perubahan bentuk dari suatu bentuk material yang digunakan. Perubahan bentuk pada Finite Element Analysis (FEA) dinyatakan displacement. Displacement total pada propeller kapal hasil analisis 
ditunjukkan pada Gambar 12. Displacement total merupakan superposisi dari displacement dari arah sumbu X, Y dan Z (Setyono, Mrihrenaningtyas, \& Hamid, 2016) yang ditunjukkan pada Gambar 13. sampai dengan Gambar 15.

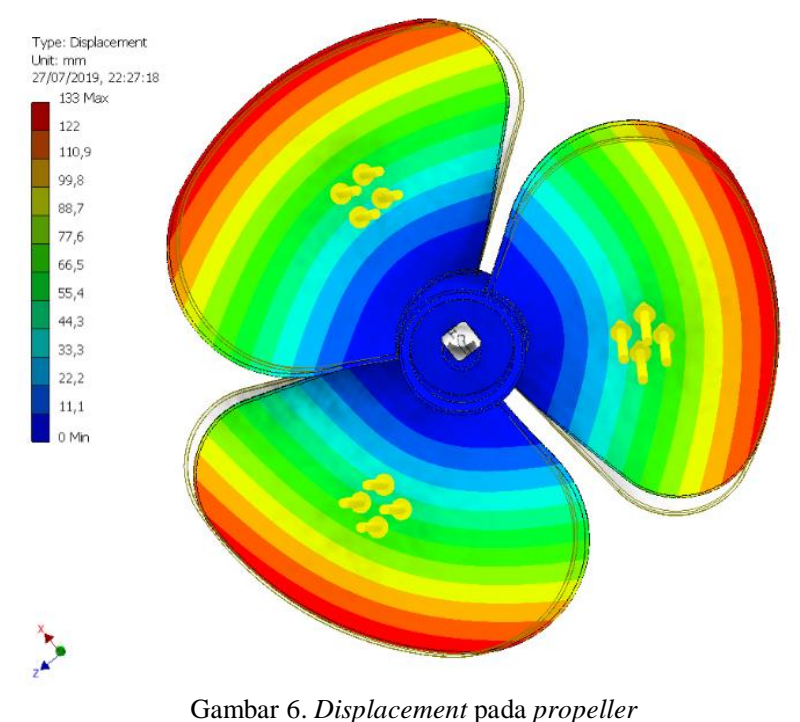

Hasil Permodelan Finite Element Analysis (FEM) dapat menganalisis displacement. Displacement maksimum pada daerah blade propeller yang paling jauh dengan lubang poros propeller yaitu sebesar $133 \mathrm{~mm}$. Peristiwa tersebut dikarenakan pengaruh gaya dorong yang seragam pada blade propeller. Displacement sangat berpengaruh pada distribusi gaya yang terjadi pada geometri benda yang dimodelkan (Pranoto \& Mahardika, 2018). Daerah yang memiliki tegangan yang paling minimum akan terjadi displacement yang paling tinggi. Respon elastisitas material pada propeller sangat berpengaruh terhadap kontur persebaran dari displacement dari lubang poros menuju ujung dari blade propeller.

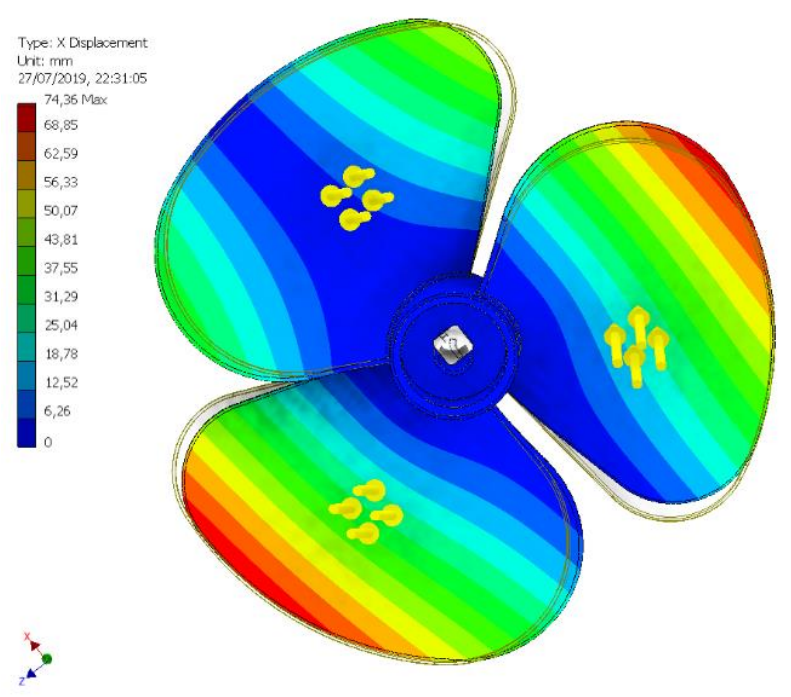

Gambar 7 Displacement pada arah X

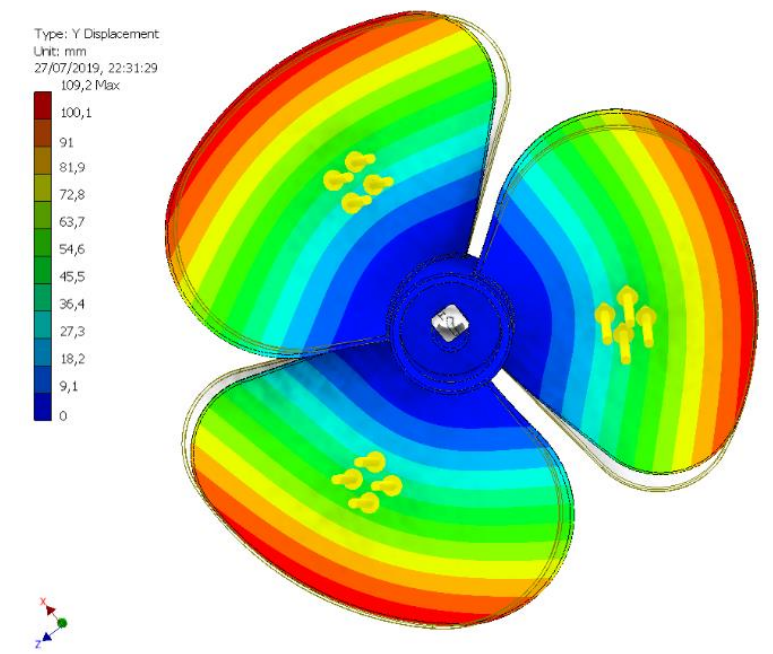

Gambar 8 Displacement pada arah Y

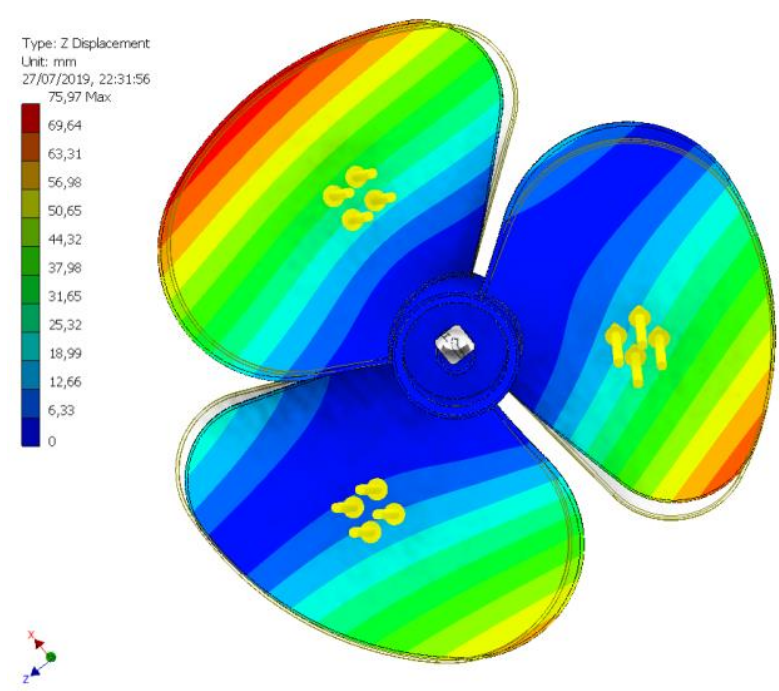

Gambar 9 Displacement pada arah Z

Displacement pada 3 sumbu menunjukkan adanya perbedaan arah kontur persebaran dari displacement propeller. Peristiwa tersebut dikarenakan arah pembebanan yang terjadi pada propeller. Arah sumbu yang tegak lurus dengan pembebanan yang memiliki nilai yang paling maksimum yaitu pada arah Y sebesar 109,2 mm. Sedangkan untuk arah sumbu $\mathrm{X}$ dan $\mathrm{Z}$ displacement berturut-turut memiliki nilai yaitu 74,36 $\mathrm{mm}$ dan 75,97 $\mathrm{mm}$.

Safety factor adalah salah satu parameter yang sangat penting dalam melakukan desain dan pengujian tegangan pada suatu bentuk geometri model bentuk benda uji untuk menentukan aman atau tidak dari bentuk tersebut (Setyono, Mrihrenaningtyas, \& Hamid, 2016). Gambar 17 menunjukkan nilai safety factor yang paling rendah pada propeller sebesar 0. Dimana nilai tersebut sangat riskan dalam menentukan keamanan propeller. hal tersebut dapat menyebabkan kegagalan material pada propeller akan mengalami kegagalan saat diaplikasikan pada beban kerja tersebut. Sedangkan safety factor yang baik digunakan pada propeller kapal yaitu lebih besar dari 1 (Reddy \& Rao, 2015). Nilai safety factor didapat dari adanya pembagian beban luluh dari material propeller kapal 
dengan beban yang diijinkan (Pratama \& Mahardika, 2018).

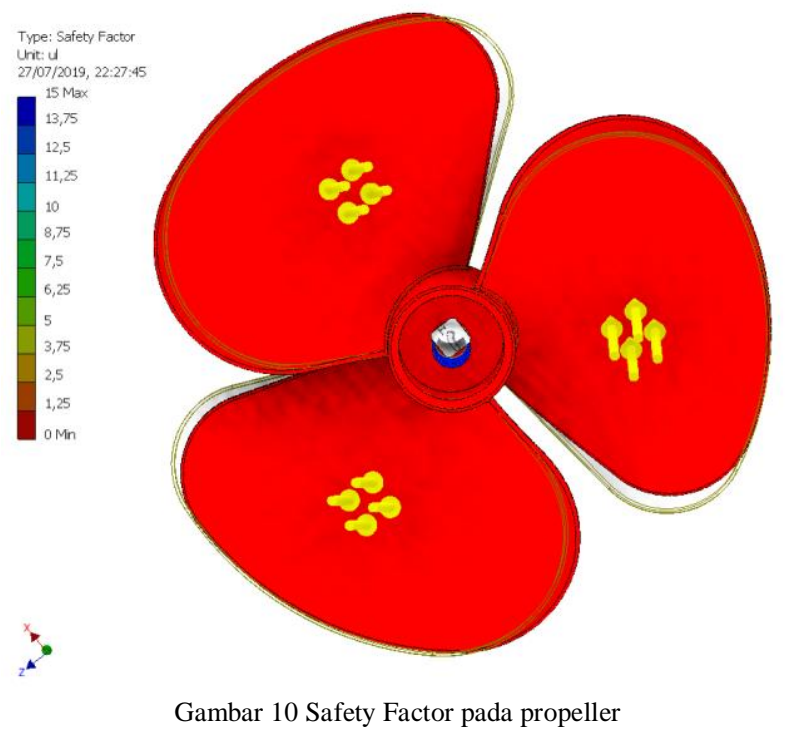

\section{PENUTUP}

\section{Kesimpulan}

Analisis pada propeller kapal dengan pembebanan $232700 \mathrm{~N}$ dapat disimpulkan bahwa geometri dari propeller mengalami ketidak amanan Sehingga propeller akan mudah mengalami deformasi atau kegagalan. Nilai safety factor sangat kecil di seluruh bagian propeller kapal, baik dibagian blade propeller maupun bagian yang lain. Peristiwa tersebut sangat mirip pada lapangan yang sering menemui terjadinya deformasi maupun kegagalan pada propeller kapal di wilayah kota Dumai. Disisi lain nilai tegangan, regangan dan displacement dari berbagai arah sumbu pembebanan mendukung nilai safety factor yang kecil pada propeller. Kontur yang dihasilkan dari tegangan dan regangan terlihat nilai maksimum berawal dari daerah sambungan blade propeller dengan lubang as propeller. sedangkan untuk kontur displacement nilai maksimum terlihat pada daerah pinggir menjauhi lubang as propeller.

\section{Saran}

Perbaikan desain dari propeller sangat diharapkan untuk keberlanjutan penelitian selanjutnya. Hal tersebut untuk menjawab solusi dari penelitian ini. Selain itu perbedaan material yang lainnya untuk diketahui kemampuannya terhadap pembebanan pada propeller kapal.

\section{DAFTAR PUSTAKA}

Babu, K. P. S., \& Padmanabhan, S. (2017). Design Of Marine Propeller Blade with Different Blade Sequences Analyse The Hydro Formation Under Pressure Hydrodynamic Fill. ARPN Journal of Engineering and Applied Sciences, 12(17), 49965002.

Carlton, J. (2007). Marine Propellers and Prolusion (Third Edit).

Dapas, S. O. (2011). Analisis Struktur Rangka Batang.
Jurnal Ilmiah Media Engineering, 1(2), 156-160.

Fadiji, T., Coetzee, C. J., Berry, T. M., Ambaw, A., \& Opara, U. L. (2018). The Efficacy of Finite Element Analysis (FEA) as A Design Tool for Food Packaging: A Review. Biosystems Engineering, 174, 20-40.

Ishak, M. A., Sulaiman, S., Baharudin, B. T. H. T., \& Syajaratunnur, Y. (2017). Research on The Ship Propeller Blade to Determine Changes in The Mechanical Properties Based on The Forces Projection. ARPN Journal of Engineering and Applied Sciences, 12(4), 1241-1247.

Khashan, M. K., Khaleel, H. H., \& Meteab, A. H. (2017). Numerical Study and Analysis of Ship Propeller. Journal of Mechanical Engineering Research and Developments, 40(4), 572-578.

Kishore S., J., Rao, B. S., \& Babu, P. K. (2015). FEM Analysis on Submarine Propeller Blade for Improved Efficiency by using Solid Works and ANSYS-Workbench. International Journal of Emerging Engineering Research and Technology, 3(11), 144-151.

Lasabuda, R. (2013). Pembangunan Wilayah Pesisir Dan Lautan Dalam Perspektif Negara Kepulauan Republik Indonesia. Jurnal Ilmiah Platax, I(2), 92101.

Lin, H. J., Lai, W. M., \& Kuo, Y. M. (2010). Effects of Stacking Sequence on Nonlinear Hydroelastic Behavior of Composite Propeller Blade. Journal of Mechanics, 26(3), 293-298.

Oladokun, S. O. (2016). Study of Efficiency and Environmental Performance of Propeller. Journal of Coastal Zone Management, 18(2).

Pranoto, S. H., \& Mahardika, M. (2018). Design and Finite Element Analysis of Micro Punch CNC Machine Modeling for Medical Devices. AIP Conference Proceedings, 1941, 1-7.

Pratama, J., \& Mahardika, M. (2018). Finite Element Analysis To Determine The Stress Distribution, Displacement And Safety Factor On A Microplate For The Fractured Jaw Case. AIP Conference Proceedings, 1941, 1-7.

Rahmi, M., Canra, D., \& Suliono, S. (2018). Analisis Kekuatan Ball Valve Akibat Tekanan Fluida Menggunakan Finite Element Analysis. JTT (Jurnal Teknologi Terapan), 4(2), 79-84.

Ramadhan, M. S., Mangalla, L. K., \& Samhuddin. (2018). Perancangan Dan Simulasi Frame Mobil Gokart. ENTHALPY-Jurnal Ilmiah Mahasiswa Teknik Mesin PERANCANGAN, 3(2), 1-10.

Rao, Y. S., Rao, K. M., \& Reddy, B. S. (2012). Stress Analysis of Composite Propeller By Using Finite Element Analysis. International Journal of Engineering Science and Technology, 4(8), 38663875 .

Reddy, T. C. K., \& Rao, K. N. (2015). Design and Simulation of A Marine Propeller. International Journal of Research in Advanced Engineering Technologies, 5(1), 111-128.

Rodriguez, N. M., \& Lade, P. V. (2013). Effects of Principal Stress Directions and Mean Normal 
Stress on Failure Criterion for Cross-Anisotropic Sand. Journal of Engineering Mechanics, 139(11), 1592-1601.

Saputro, A. H., Hidayat, T., \& Qomaruddin. (2017). Analisa Poros Alat Uji Keausan Untuk Sistem Kontak Two-Disc Dengan Menggunakan Metode Elemen Hingga. Simetris: Jurnal Teknik Mesin, Elektro Dan Ilmu Komputer, 8(1), 283-290.

Setyono, B., Mrihrenaningtyas, \& Hamid, A. (2016). Perancangan Dan Analisis Kekuatan Frame Sepeda Hibrid "Trisona" Menggunakan Software Autodesk Inventor. Jurnal IPTEK, 20(2), 37.

Suneetha, M., Rao, R. S., Vardhan, V. V., \& Gowd, G. H. (2013). Design \& Analysis of a Surface Propeller using FEM. International Journal of Emerging Technology and Advanced Engineering, 3(9), 198204.

Syafrizal. (2017). Analisis Tegangan Batang Lentur Tumpuan Jepit dan Roll pada Material Stainless Stell. ELEKTRA, 2(2), 93-100.

Tan, Y., Li, J., Li, Y., \& Liu, C. (2019). Improved Performance Prediction of Marine Propeller: Numerical Investigation and Experimental Verification. Mathematical Problems in Engineering, 2019.

Wandono, F. A. (2017). Permodelan Metode Elemen Hingga Untuk Menentukan Tegangan Von Mises Pada As Roda Lsu-05. Seminar Nasional Iptek Penerbangan Dan Antariksa XXI, 222-231.

Zainol, I., \& Yaakob, O. (2016). Use of Diesel Engine and Surface-Piercing Propeller to Achieve Fuel Savings for Inshore Fishing Boats. Journal of Marine Science and Application, 15(2), 214-221. 